\title{
Preeclampsia - Aetiology, Current Diagnostics and Clinical Management, New Therapy Options and Future Perspectives
}

\section{Präeklampsie - Ätiologie, aktuelle Diagnostik und klinisches Management, neue Therapieoptionen und Zukunftsaussichten}

Authors

Affiliations
A.-C. Tallarek ${ }^{1}$, B. Huppertz ${ }^{2}$, H. Stepan ${ }^{1}$

${ }^{1}$ Department of Obstetrics, University Hospital Leipzig, Leipzig

${ }^{2}$ Institute for Cell Biology, Histology and Embryology, Medical University Graz, Graz, Austria
Key words

- hypertensive diseases

of pregnancy

- preeclampsia

- angiogenic balance

Schlüsselwörter

- hypertensive Schwangerschaftserkrankungen

- Präeklampsie

- angiogene Balance

\section{received $\quad 5.10 .2012$ \\ revised 28.11.2012 \\ accepted 28.11.2012}

Bibliography

DOI http://dx.doi.org/

10.1055/s-0032-1328080

Geburtsh Frauenheilk 2012; 72 :

1107-1116 @ Georg Thieme

Verlag KG Stuttgart · New York ISSN 0016-5751

\section{Correspondence}

Prof. Dr. Holger Stepan

University Hospital Leipzig

Department of Obstetrics

Liebigstraße 20 a

04103 Leipzig

holger.stepan@

medizin.uni-leipzig.de

\section{Abstract}

$\nabla$

Preeclampsia is a multisystem disease for which the exact causes have not yet been sufficiently clarified. However, in the past few years it has become clear that a placental imbalance between angiogenic and anti-angiogenic proteins is the decisive pathogenetic factor for the occurrence of preeclampsia. With the possibility to measure these angiogenic factors (sFlt-1/PlGF ratio) in maternal blood full new diagnostic possibilities have been opened that enable the certain diagnosis or exclusion of the diseases as well as a short-term prognosis to be made. In secondary prevention the current data situation for ASA confirms a moderate but measurable utility. The management concept depends on gestational age. In the case of early clinical manifestations (<34th week of pregnancy) the clinical management in a perinatal centre remains unchanged with foeto-maternal monitoring and induction of pulmonary maturation, symptomatic therapy under careful blood pressure lowering and determination of the optimal delivery time. A balance must be made here between foetal immaturity and maternal risks upon prolongations. The pathomechanism of anti-angiogenic overload with sFlt-1 provides a starting point for first therapeutic interventions. The present article gives an overview of current diagnostic options and presents possible future therapeutic perspectives for discussion.

\section{Introduction}

$\nabla$

Preeclampsia is a serious and potentially lifethreatening disease appearing as a complication in about $2-5 \%$ of all pregnancies and associated with significant perinatal and maternal mortality $[1,2]$. It is estimated that more than 60000 wom-

\section{Zusammenfassung \\ $\nabla$}

Die Präeklampsie ist eine Multisystemerkrankung, deren genaue Ursache noch nicht hinreichend geklärt ist. Allerdings ist in den letzten Jahren klar geworden, dass ein plazentares Ungleichgewicht zwischen angiogenen und antiangiogenen Proteinen der entscheidende pathogenetische Faktor für die Entstehung der Präeklampsie ist. Mit der Möglichkeit der Messung dieser angiogenen Faktoren (sFlt-1/PlGF-Quotient) im maternalen Blut ergeben sich völlig neue diagnostische Möglichkeiten, die die sichere Diagnose bzw. den Ausschluss der Erkrankung und darüber hinaus eine Kurzzeitprognose ermöglichen. In der Sekundärprävention belegt die Datenlage für ASS einen moderaten, aber doch messbaren Nutzen. Das Betreuungskonzept ist abhängig vom Gestationsalter. Bei früher klinischer Manifestation $(<34$. SSW) ist das klinische Management im Perinatalzentrum unverändert die fetomaternale Überwachung mit Induktion der Lungenreife, symptomatischer Therapie unter vorsichtiger Blutdrucksenkung und Festlegung des optimalen Entbindungszeitpunkts. Abgewogen werden muss hierbei die fetale Unreife gegen die fetalen und maternalen Risiken bei Prolongation. Der Pathomechanismus des antiangiogenen Overloads mit sFlt-1 liefert einen Ansatz für erste therapeutische Interventionen. Der vorliegende Beitrag gibt einen Überblick in die aktuellen diagnostischen Möglichkeiten und stellt eventuelle Therapieaussichten in der Zukunft zur Diskussion.

\section{Einleitung \\ $\nabla$}

Die Präeklampsie ist eine schwere und potenziell lebensbedrohliche Erkrankung, die etwa 2-5\% aller Schwangerschaften kompliziert und mit einer signifikanten perinatalen und maternalen Morbidität assoziiert ist [1,2]. Weltweit versterben schätzungs- 
en worldwide die of the disease each year, it is one of the main causes of maternal mortality [3]. There are as yet no theories as to its causes so that today complications can only be avoided by early delivery. This leads to a premature birth due to highly iatrogenic causes with all its consequences. In addition, numerous studies in the past few years have confirmed that the afflicted women have a risk disposition for the rest of their lives for cardiovascular diseases (stroke, heart attack), type II diabetes or metabolic syndrome $[4,5]$.

\section{Aetiology and Pathogenesis}

Because of its unknown aetiology preeclampsia was considered for a long time to be a "disease of theories". Even today, the molecular basis for the placental dysregulation, which very probably leads to the disease, has not yet been sufficiently clarified. Numerous immunological, inflammatory and genetic factors play a role in this process. Foundation for the clinical picture is an inadequate differentiation of trophoblasts in early pregnancy. This leads in turn to a dysregulation of the villous trophoblasts which now besides the secretion of apoptotic structures also liberate increased amounts of necrotic microparticles. These enter the maternal blood, there lead to dysfunction of endothelial cells and to systemic inflammatory reaction, both of which are typical for preeclampsia [6,7].

Recently increasing evidence has been gathered that a disorder of the placental equilibrium between angiogenic (PIGF: placental growth factor, VEGF: vascular endothelial growth factor) and anti-angiogenic ( sFlt-1 = soluble fms-like tyrosine kinase-1) factors plays a central role in the clinical development of hypertensive diseases of pregnancy. A shift of the balance towards an excess of anti-angiogenic factors seems to be the central factor for preeclampsia and other placental pathologies (IUGR, placental abruption).

sFlt- 1 is a soluble fragment of the VEGF receptor- 1 and serves as mediator of the disease. In the status of preeclampsia it is produced in increased amounts in the placenta, released into the circulation and inhibits angiogenic factors such as PIGF and VEGF. VEGF and PIGF bound to sFit-1 can no longer bind to the corresponding receptors on endothelial cells resulting in a disturbance of VEGF signal transmission [8-10] (๑ Fig. 1).

This angiogenic misbalance correlates with the severity of the disease and can even be detected prior to the occurrence of clinical symptoms [11].

The disturbed intracellular signal transmission influences the morphology and function of endothelial cells. All clinical manifestations of preeclampsia can be attributed to this generalised endothelial dysfunction: glomerular endotheliosis, increased vessel permeability and a systemic inflammatory response develop, leading to hypoperfusion and damage to the end organs [12]. Osmanagaoglu et al. examined ischaemic factors with regard to their use in the early detection of preeclampsia. It was shown that maternal carnitine, ADMA and IMA concentrations are elevated in pregnant women with preeclampsia whereas in contrast the L-arginine concentrations are reduced. However, as yet it has not been possible to identify an independent parameter [13].

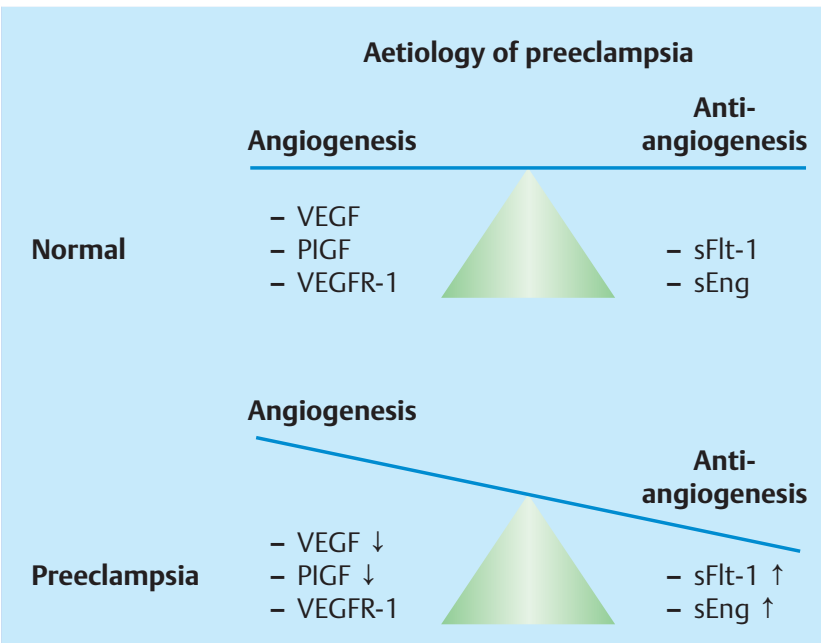

Fig. 1 Angiogenic imbalance of preeclampsia.

weise mehr als 60000 Frauen jährlich, die Erkrankung zählt zu den Hauptursachen der Müttersterblichkeit [3]. Bisher existiert keine ursächliche Therapie, sodass zum jetzigen Zeitpunkt Komplikationen nur durch eine vorzeitige Entbindung verhindert werden können. Dies führt zu einer hohen iatrogen verursachten Frühgeburtlichkeit mit all ihren Konsequenzen. Darüber hinaus belegen zahlreiche Studien in den letzten Jahren, dass nach einer Präeklampsie für die betroffene Frau lebenslang eine Risikodisposition für kardiovaskuläre Erkrankungen (Schlaganfall, Herzinfarkt), Typ-II-Diabetes oder ein metabolisches Syndrom besteht $[4,5]$.

\section{Ätiologie und Pathogenese}

Die Präeklampsie galt aufgrund ihrer unklaren Ätiologie lange Zeit als „Krankheit der Theorien“. Auch aktuell ist die molekulare Basis der plazentaren Dysregulation, die sehr wahrscheinlich zu der Erkrankung führt, noch nicht hinreichend geklärt. Zahlreiche immunologische, inflammatorische und genetische Faktoren spielen bei diesem Prozess eine Rolle. Grundlage des Krankheitsbilds ist eine mangelhafte Differenzierung des Trophoblasten in der Frühschwangerschaft. Hierdurch kommt es zu einer Fehlregulation des Zottentrophoblasten, der nun neben der Abgabe von apoptotischen Strukturen vermehrt auch nekrotische Mikropartikel freisetzt. Diese gelangen ins maternale Blut und führen dort zur Dysfunktion der Endothelzellen und zur systemischen Inflammationsreaktion, die beide typisch für eine Präeklampsie sind [6,7].

In letzter Zeit gibt es zunehmende Evidenz, dass eine Störung des plazentaren Gleichgewichts zwischen angiogenen (PIGF: „placental growth factor“, VEGF: „Vascular endothelial growth factor“") und antiangiogenen (sFlt-1 = soluble fms-like tyrosine kinase-1) Faktoren eine zentrale Rolle in der klinischen Ausprägung hypertensiver Schwangerschaftserkrankungen spielt. Eine Verschiebung dieser Balance zu einem Überschuss an antiangiogenen Faktoren scheint der zentrale Faktor für die Präeklampsie und andere plazentare Pathologien (IUGR, vorzeitige Plazentalösung) zu sein.

sFlt- 1 ist ein lösliches Fragment des VEGF-Rezeptors-1 und fungiert als Mediator der Erkrankung. Es wird im Zustand der Präeklampsie vermehrt in der Plazenta produziert, in die Zirkulation freigesetzt und inhibiert angiogene Faktoren wie PIGF und VEGF. An sFlt-1 gebundenes VEGF und PIGF kann nicht mehr an die entsprechenden Re- 


\section{Current Diagnostics}

\section{$\nabla$}

The diagnosis of preeclampsia is still based on the clinical signs of hypertension ( $\geq 140 / 90 \mathrm{mmHg}$ ) and proteinuria $(\geq 300 \mathrm{mg} / 24 \mathrm{~h}$ ). In HELLP syndrome, a special form of preeclampsia that is also characterised by elevated sFlt- 1 concentrations, the diagnosis involves further laboratory tests such as thrombocyte count, liver enzymes and haemolysis parameters. In clinical routine it is not a trivial matter to make a secure diagnosis. Often physiological changes of pregnancy such as, for example, oedema formation near term, overlap with the phenotype of preeclampsia and not all clinical symptoms such as, e.g., headache or upper abdominal pain can be attributed to a hypertensive complication of pregnancy. Also in the situation of a generalised seizure, the clinical differentiation between an eclamptic seizure and a seizure due to other causes (e.g., epilepsy) is difficult.

In a large English study it was shown that in the course ca. $10 \%$ of all pregnancies the clinical signs of preeclampsia were seen by physicians whereas only one in five of these patients actually developed a hypertensive complication of pregnancy [14]. The situation "suspicion of preeclampsia" leads in Germany to about $20 \%$ of the prepartal hospital admissions. The secure diagnosis or, respectively, the certain exclusion of the disease is an important target, on the one hand to avoid fatal consequences and, on the other hand, to avoid over-treatment and unnecessary anxiety for the pregnant woman.

With the introduction of the automatic measurement of the biomarkers sFlt- 1 and PIGF, an additional diagnostic test is available for clinical routine. A multicentre study has shown that a cut-off of 85 for the sFlt-1/PIGF ratio identifies preeclampsia with a sensitivity of $82 \%$ and a specificity of $95 \%$. The test quality is even somewhat better in preeclampsias with early manifestations (<34th week of pregnancy) (sensitivity $89 \%$, specificity $97 \%$ ). Furthermore, other hypertensive diseases of pregnancy can be differentiated ( $\bullet$ Fig. 2).

First results have shown that, especially in outpatient settings, a secure diagnosis excluding preeclampsia is possible with unremarkable ratios (<85). [15]. Further studies are needed to evaluate the time interval at which the angiogenic factors should be determined since a negative sFlt-1 ratio only excludes preeclampsia at the time of measurement but not that it can develop later.

In cases of manifest preeclampsia. the question arises whether or not knowledge of the serum concentrations of the angiogenic factors has any additional value. In this context first results have shown that the Flt-1 concentration or, respectively, the sFlt-1/ PIGF ratio makes possible a short-term prognosis for the clinical course of the pregnancy or, respectively, demonstrates the degree of progression of the disease. In a study by Verlohren et al. it was shown that, in cases of clinically manifest preeclampsia prior to the 34th week of pregnancy, an sFlt-1/PIGF ratio above the 3rd quartile (>655.2) indicates the highest risk for an impending delivery. At 48 hours later only $29.4 \%$ of these pregnant women had not yet given birth to their babies (95\% CI 14.1-61.4, $\mathrm{p}=0.016$ ), whereas $50 \%$ (CI 38.1-65.6) of the patients with an sFlt-1-PIGF ratio below the 3rd quartile were still pregnant at this time [16]. After 7 days only $5.9 \%$ of the patients with a ratio above the 3rd quartile were still pregnant in comparison to $30.8 \%$ in the subgroup with a lower sFLT1-PIGF ratio.

These results were confirmed in a prospective study of over 600 pregnant women referred to hospital with the diagnosis of suspected preeclampsia. The size of the ratio here also correlated zeptoren auf der Endothelzelle binden, es kommt zu einer gestörten VEGF-Signalübertragung [8-10] ( $\bullet$ Abb. 1).

Diese angiogene Imbalance korreliert mit dem Schweregrad der Erkrankung und ist bereits vor dem Auftreten der klinischen Symptome nachweisbar [11].

Die gestörte intrazelluläre Signalübertragung beeinflusst die Morphologie und Funktion der Endothelzellen. Alle klinischen Manifestationen der Präeklampsie lassen sich auf diese generalisierte endotheliale Dysfunktion zurückführen: es entwickelt sich eine glomeruläre Endotheliose, eine erhöhte Gefäßpermeabilität und eine systemische inflammatorische Antwort, die zu einer Hypoperfusion und Schädigung von Endorganen führt [12].

Osmanagaoglu et al. untersuchten Ischämiefaktoren im Hinblick auf ihren Nutzen in der Früherkennung einer Präeklampsie. Sie konnten zeigen, dass mütterliche Carnitin-, ADMA- und IMA-Konzentrationen bei präeklamptischen Schwangeren erhöht waren, wogegen die LArginin-Konzentrationen verringert waren. Allerdings gelang es bisher nicht, einen unabhängigen Parameter zu identifizieren [13].

\section{Aktuelle Diagnostik \\ $\nabla$}

Die Diagnostik der Präeklampsie beruht weiterhin auf den klinischen Zeichen einer Hypertonie $(\geq 140 / 90 \mathrm{mmHg})$ und Proteinurie $(\geq 300 \mathrm{mg} / 24 \mathrm{~h})$. Beim HELLP-Syndrom, einer Sonderform der Präeklampsie, die ebenfalls durch erhöhte sFlt-1-Konzentrationen gekennzeichnet ist, erfolgt die Diagnose durch weiterführende Laboruntersuchungen, wie Thrombozytenzahl, Leberenzymen und Hämolyseparametern. In der klinischen Routine ist es keinesfalls trivial, eine sichere Diagnose zu stellen. Häufig überschneiden sich physiologische Schwangerschaftsveränderungen, wie z.B. Ödeme in Terminnähe, mit dem Phänotyp der Präeklampsie und nicht alle klinischen Symptome, wie z.B. Kopf- oder Oberbauchschmerzen, sind auf eine hypertensive Schwangerschaftskomplikation zurückzuführen. Auch in der Situation eines generalisierten Krampfanfalls ist die klinische Differenzierung zwischen einem eklamptischen Anfall und einem Krampfanfall anderer Genese (z. B. Epilepsie) schwierig.

In einer großen englischen Studie konnte gezeigt werden, dass ca. 10\% aller Schwangerschaften im Verlauf der Schwangerschaft mit klinischen Zeichen einer Präeklampsie ärztlich gesehen werden, aber nur jede 5. dieser Patientinnen tatsächlich eine hypertensive Schwangerschaftskomplikation hat [14]. Die Situation „Verdacht auf Präeklampsie“ führt in Deutschland zu ca. $20 \%$ der präpartalen stationären Einweisungen. Die klare Diagnose bzw. der Ausschluss der Erkrankung ist ein wichtiges Ziel, einerseits um fatale klinische Konsequenzen zu vermeiden, andererseits um eine Überbehandlung bzw. unnötige Beunruhigung der Schwangeren zu vermeiden.

Durch die Einführung der automatisierten Messung der Biomarker sFlt-1 und PIGF steht in der klinischen Routine ein zusätzlicher diagnostischer Test zur Verfügung. Eine Multicenterstudie konnte zeigen, dass ein Cut-off von 85 des sFlt-1/PIGF-Quotienten eine Präeklampsie mit einer Sensitivität von $82 \%$ und einer Spezifität von $95 \%$ erkennt. Die Testqualität ist bei Präeklampsien mit früher Manifestation (<34. SSW) noch etwas besser (Sensitivität $89 \%$, Spezifität $97 \%$ ). Weiterhin können andere hypertensive Schwangerschaftserkrankungen von der Präeklampsie differenziert werden ( $\triangle$ Abb. 2).

Erste Ergebnisse zeigen, dass vor allem auch im ambulanten Bereich eine sichere Ausschlussdiagnostik der Präeklampsie bei unauffälligem Quotienten (<85) möglich ist [15]. Weitere Studien müssen evaluieren, in welchem Zeitintervall die angiogenen Faktoren kontrolliert werden sollten, da ein negativer sFlt-1-Quotient zwar aus- 
Possibilities and uses of sFlt1/PIGF measurements

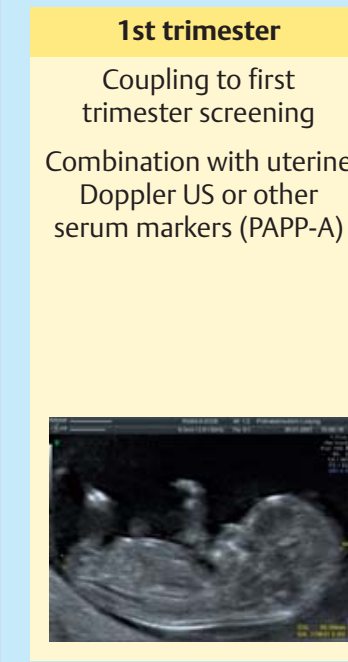

Future!

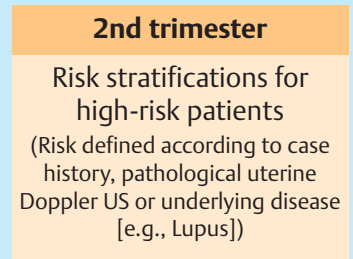

Appropriate monitoring for patients at high risk!

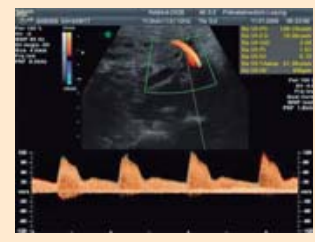

Possible!

Ongoing prospective trials

3rd trimester
Clarification of clinically
uncertain situations

uncertain situations

Exclusion diagnostics

for "suspicion

of preeclampsia"

Monitoring the clinical situation for severe preeclampsia/HELLP

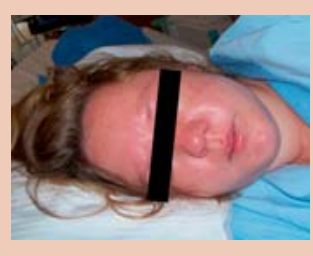

Available!

Established commercial tests with norm values
Fig. 2 Proposal for the use of angiogenic factors or, respectively, thesFIt-1/PIGF ratio referred to pregnancy trimester.

(C) Stepan 2011

negatively with the time interval between admission and delivery. While, at referral before the 34th week of pregnancy with the diagnosis suspicion of preeclampsia and an sFlt-1/PIGF ratio $>85,86 \%$ of the pregnant women gave birth in the next 2 weeks because of complications or clinical necessity, this was the case for only $15.8 \%$ with an sFlt-1/PIGF ratio < 85 [17]. For the prediction of an adverse outcome, this test is better than the established clinical criteria like blood pressure or laboratory parameters such as uric acid and liver enzymes. These results impressively demonstrate how the rate of progression of the disease or, respectively, the clinical aggressiveness of the disease correlates with the angiogenic factors and that this can be used in the practical/clinical management of the disease [39].

\section{First Trimester Screening}

$\nabla$

A further desirable target is the early detection of an increased risk for preeclampsia in order to include the respective pregnant women in an intensive management concept. A coupling with first trimester screening appears to be reasonable.

In the framework of first semester screening it was noticed that women with low PAPP-A values but with normal karyotypes developed preeclampsia or IUGR in the further course of pregnancy more often. Thus, in a report by Poon et al. published in 2009 it was shown that the risk for a later preeclampsia increased dramatically from an $\mathrm{MOM} \leq 0.4$ of the pregnancy-associated plasma protein-A (PAPP-A) value [18]. In the meantime a module is available to calculate the risk for preeclampsia utilising the PAPP-A value. Subsequently, further reports were published showing that pregnant women who later developed preeclampsia exhibited lowered PIGF values already at the time of the first trimester screening. Through the combined use of, for example, uterine perfusion values, maternal blood pressure, serum PAPP-A and serum PIGF, it is possible to define an individual risk profile for the later occurrence of preeclampsia. schließt, dass zum Zeitpunkt der Messung eine Präeklampsie vorliegt, sich diese aber später noch entwickeln kann.

Bei manifester Präeklampsie stellt sich die Frage, ob die Kenntnis der Serumkonzentrationen der angiogenen Faktoren einen klinischen Mehrwert bringt. Hier gibt es erste Ergebnisse, die zeigen, dass die sFlt-1-Konzentration bzw. der sFlt-1/PlGF-Quotient eine Kurzzeitprognose für den klinischen Verlauf der Schwangerschaft ermöglicht bzw. den Grad der Progression der Erkrankung anzeigt. In einer Studie von Verlohren et al. konnte gezeigt werden, dass bei klinisch manifester Präeklampsie vor der 34. SSW die Schwangerschaften, die eine sFlt-1/PlGF-Ratio oberhalb der 3. Quartile hatten $(>655,2)$ das höchste Risiko für eine sehr zeitnahe Entbindung hatten. Nach 48 Stunden waren nur 29,4\% dieser Schwangeren noch nicht entbunden (95\%-KI 14,1-61,4, p=0,016), während 50\% (KI 38,1-65,6) von den Patienten, die eine sFlt-1-PIGF-Ratio unterhalb der 3. Quartile hatten, immer noch schwanger waren [16]. Nach 7 Tagen waren nur 5,9\% der Patientinnen mit einem Quotienten oberhalb der 3. Quartile noch schwanger im Vergleich zu 30,8\% der Subgruppe, die einen niedrigeren sFLT1-PIGF-Quotienten hatte.

Diese Ergebnisse konnten durch eine prospektive Untersuchung mit über 600 Schwangeren, die sich mit der Verdachtsdiagnose Präeklampsie in der Klinik vorstellten, bestätigt werden. Die Höhe des Quotienten korrelierte auch hier negativ mit dem Zeitintervall zwischen Vorstellung und Entbindung. Waren bei Vorstellung vor der 34. SSW aufgrund des „Verdachts auf Präeklampsie“ und einem sFlt1/PlGF-Quotienten > 85 innerhalb der nächsten 2 Wochen $86 \%$ dieser Schwangeren aufgrund einer Komplikation bzw. klinischen Notwendigkeit entbunden, waren es nur 15,8\%, wenn der sFlt-1/Quotient $<85$ war [17]. In der Vorhersage eines „adverse outcome“ ist dieser Test besser als die etablierten klinischen Kriterien wie Blutdruck oder Laborparameter wie Harnsäure und Leberenzyme. Diese Zahlen zeigen sehr eindrücklich, wie die Progressionsgeschwindigkeit der Erkrankung bzw. die klinische Aggressivität der Erkrankung mit den angiogenen Faktoren korreliert und dies kann für das praktisch-klinische Management genutzt werden [39]. 
Other candidate markers have also been studied with regard to their potential to detect a later risk for preeclampsia already in the first trimester. These include PP-13, soluble endoglin, inhibin A, activin A, pentraxin 3 or p-selectin. All these markers are essentially of placental origin with the exception of pentraxin 3, an endothelium-derived protein. In a study by Akolekar in 2011 it was demonstrated that use of a combination of maternal factors like uterine Doppler US scans and blood pressure together with the above-mentioned markers was able to recognise, with a false-positive rate of merely $5 \%$, an early onset preeclampsia with a detection rate of $91 \%$ and a late-onset preeclampsia with a detection rate of $60.9 \%$ [20]. Ultimately, in the future when the results of further, larger studies become available it will be possible to see which markers in which combinations will be useful for the clinical routine.

Doppler ultrasound of the two uterine arteries in the course of fine diagnostics at the 20th week of pregnancy is still the standard for the prediction of preeclampsia. In the case of pathological findings, an intensive monitoring should be initiated with the objective to diagnose a possibly developing preeclampsia as early as possible and thus to avoid serious complications.

\section{Clinical Management}

\section{$\nabla$}

In spite of the progress in research on aetiology, there are as yet no causal therapies. The sole curative therapy for preeclampsia and HELLP syndrome is delivery of the baby or, respectively, removal of the placenta from the mother's body [21]. Drug therapy is always merely a symptomatic treatment of the functional disturbances in the maternal organism and has the major purpose to extend the pregnancy in order to avoid a premature birth with the resulting detrimental consequences for the perinatal outcome. Such a conservative management is indicated between the 24th and 34th weeks of pregnancy. The primary objective in this situation is the induction of pulmonary maturation in the foetus by administration of glucocorticoids. On average, a prolongation of 5-10 days can be achieved which, especially between the 24th and 26th week of pregnancy, can decisively improve the baby's chances of survival.

Indications for terminating the pregnancy are therapy-refractive hypertensive crises, persisting central nervous symptoms in the form of headache, vomiting or flickering spots in front of the eyes, an increasing oligo- or anuria, declining thrombocyte counts or, respectively, decompensated coagulation parameters in HELLP syndrome or signs of foetal distress (pathological CTG). Even in cases of severe preeclampsia with blood pressures $\geq 170$ / $110 \mathrm{mmHg}$ and proteinuria of more than $5 \mathrm{~g} / \mathrm{d}$, prolongation of the pregnancy should be discussed critically. In such a situation the maternal risks on prolongation of the pregnancy must be weighed against the benefits for the baby. After the 34th week of pregnancy, in cases with confirmed preeclampsia or HELLP syndrome, the pregnancy should always be terminated. If life-threatening complications due to a multisystem disease arise, monitoring of the patient in the intensive care unit is necessary. About $40 \%$ of all obstetric admissions to the ICU are due to hypertensive diseases of pregnancy [22].

\section{Treatment of Hypertension}

Benefits for foetal development and thus an improvement of the baby's prognosis resulting from blood pressure lowering drug treatment have not yet been proven. Current meta-analyses of

\section{First-Trimester-Screening}

\section{$\nabla$}

Ein weiteres wünschenswertes Ziel ist die frühzeitige Erkennung eines erhöhten Präeklampsierisikos, um die entsprechenden Schwangeren in ein intensiviertes Betreuungskonzept einbinden zu können. Sinnvoll erscheint eine Koppelung mit dem First-TrimesterScreening.

Im Rahmen des First-Trimester-Screenings war aufgefallen, dass Frauen mit niedrigen PAPP-A-Werten, aber normalem Karyotyp im weiteren Schwangerschaftsverlauf häufiger Präeklampsien oder eine IUGR entwickelten. So konnte in einer Arbeit von Poon et al. aus dem Jahr 2009 gezeigt werden, dass das Risiko für eine spätere Präeklampsie ab einem MOM $\leq 0,4$ des PAPP-A-Wertes dramatisch ansteigt [18]. Mittlerweile gibt es Module für die Risikoberechnung bezüglich Präeklampsie unter Verwendung des PAPP-A-Wertes. Weiterführend gibt es andere Arbeiten, die zeigen, dass Schwangere mit späterer Präeklampsie schon zum Zeitpunkt des First-Trimester-Screenings erniedrigte PIGF-Werte haben [19]. Durch die kombinierte Nutzung von zum Beispiel uterinen Perfusionswerten, mütterlichem Blutdruck, Serum PAPP-A und Serum PIGF besteht die Möglichkeit, ein persönliches Risikoprofil für das spätere Auftreten einer Präeklampsie zu erstellen.

Andere Kandidatenmarker wurden ebenfalls hinsichtlich ihrer Potenz untersucht, im First-Trimester das Risiko für eine spätere Präeklampsie zu erkennen. Dazu gehören PP-13, solubles Endoglin, Inhibin A, Activin A, Pentraxin 3 oder p-Selectin. Alle diese Marker sind im Wesentlichen plazentaren Ursprungs mit Ausnahme von Pentraxin 3, welches ein endothelabgeleitetes Protein ist. In einer Studie von Akolekar aus dem Jahr 2011 konnte demonstriert werden, dass eine Kombination von maternalen Faktoren wie Uterina-Doppler und Blutdruck in Kombination mit den o.g. Markern in der Lage ist, bei einer Falsch-positiv-Rate von 5\% eine Early-Onset-Präeklampsie mit einer Detektionsrate von $91 \%$ und eine Late-Onset-Präeklampsie mit einer Detektionsrate von 60,9\% zu erkennen [20]. Letztendlich wird in Zukunft bei Vorliegen weiterer großer Studien eine Klärung erfolgen, welche Marker in welcher Kombination für die klinische Routine verwertbar sein werden.

Zum Standard der Prädiktion einer Präeklampsie gehört weiterhin die Doppler-Sonografie beider Uterinarterien im Rahmen der Feindiagnostik mit 20 SSW. Bei pathologischen Befunden sollte eine intensivierte Betreuung zum Ziel haben, dass eine eventuell sich entwickelnde Präeklampsie frühzeitig diagnostiziert und ernsthafte Komplikationen vermieden werden.

\section{Klinisches Management}

\section{$\nabla$}

Trotz der Fortschritte in der Erforschung der Ätiologie existiert bisher keine ursächliche Therapie. Die einzige kurative Therapie der Präeklampsie und des HELLP-Syndroms ist die Entbindung bzw. die Entfernung der Plazenta aus dem mütterlichen Körper [21]. Eine medikamentöse Therapie ist immer nur eine symptomatische Behandlung der Funktionseinschränkungen des maternalen Organismus und hat als vorrangiges Ziel eine Prolongation der Schwangerschaft, um eine Frühgeburt mit nachteiligen Folgen für das perinatale Outcome zu vermeiden. Ein derartiges konservatives Management ist zwischen 24 und 34 Schwangerschaftswochen indiziert. Primäres Ziel in dieser Situation ist die Lungenreifeinduktion beim Feten durch die Gabe von Glukokortikoiden. Im Durchschnitt kann eine Prolongation von 510 Tagen erreicht werden, die insbesondere zwischen 24 und 26 SSW die Überlebenschancen der Feten entscheidend verbessert. 
Table 1 Oral antihypertensive drugs for use in pregnancy.

\begin{tabular}{|lll|} 
Active principle & $\begin{array}{l}\text { Preparation } \\
\text { (e.g.) }\end{array}$ & Dosage \\
\hline alpha-Methyldopa & Presino $^{\circledR}$ & $3 \times 250 \mathrm{mg} / \mathrm{d}(\max .2000 \mathrm{mg} / \mathrm{d})$ \\
\hline Metoprolol & ${\text { Beloc } \text { mite }^{\circledR}}^{\circledR}$ & $2 \times 47.5 \mathrm{mg} / \mathrm{d}(\max .190 \mathrm{mg} / \mathrm{d})$ \\
\hline Atenolol & Tenormin $^{\circledR}$ & $2 \times 25 \mathrm{mg} / \mathrm{d}(\max .100 \mathrm{mg} / \mathrm{d})$ \\
\hline Nifedipine & Adalat retard $^{\circledR}$ & $2 \times 20 \mathrm{mg} / \mathrm{d}(\max .80 \mathrm{mg} / \mathrm{d})$ \\
\hline
\end{tabular}

numerous studies on drug-induced blood pressure reduction in moderate preeclampsia $(<170 / 110 \mathrm{mmHg}$ ) have revealed that this is accompanied by a higher rate of growth retarded infants and reduced birth weights [23].

The mainstay of therapy is thus the avoidance of maternal cerebro- and cardiovascular complications. Antihypertensive therapy should only be initiated at blood pressure values $\geq 170$ / $110 \mathrm{mmHg}$ - in cases of pre-existing high pressure or thrombotic constellations - already at blood pressure values $\geq 160$ / $100 \mathrm{mmHg}$ [24]. The aim of drug therapy is to reduce blood pressure to values in the order of 140-160/90-100 mmHg. Untreated blood pressure values in the range of 160-170 systolic and 100$110 \mathrm{mmHg}$ diastolic can, on account of the maternal risks, only be tolerated for short times, when they remain asymptomatic and when they are under continuous observation because, in particular in preeclampsia, the cerebral vascular system has not yet become adapted to high blood pressure values so that a breakdown of the cerebrovascular autoregulation with the danger of subsequent cerebral hyperperfusion cannot be excluded.

Various antihypertensive agents can be used as drug therapy. For long-term regulation the agent of choice is methyldopa with its central agonistic action on alpha-receptors. The maximal dose is $2000 \mathrm{mg} / \mathrm{d}$ spread over 4 doses. Second choice drug is a cardioselective beta blocker which, however, should not be used in cases with intrauterine retardation since very recent meta-analyses have described lower birth weights under beta blocker therapy. The vasodilator dihydralazine is nowadays hardly ever used on account of its unfavourable maternal side effect profile (headache, reflex tachycardia, restricted renal function), that correspond to the symptoms of a threatening eclampsia.

Oral drugs are summarised in the following table ( $\bullet$ Table $\mathbf{1}$ ).

For an acute reduction of blood pressure the calcium channel blocker nifedipine in its oral application form can be used. The alpha-receptor antagonist urapidil is available for intravenous therapy. Doses can be seen in the following table ( Table 2 ).

\section{Treatment of Eclampsia}

Magnesium is used as a vasorelaxing agent in the prophylaxis against and therapy for eclampsia $[25,26]$. Brain perfusion is improved by the reduction of resistance of the cerebral vessels, thus reducing the risk of eclampsia. However, an overdose can lead to respiratory depression, thus upon intravenous administration of magnesium one should monitor the respiratory frequency ( $>12$ /
Indikationen zur Beendigung der Schwangerschaft sind therapierefraktäre hypertensive Krisen, eine persistierende zentralnervöse Symptomatik in Form von Kopfschmerzen, Erbrechen oder Augenflimmern, eine zunehmende Oligo- oder Anurie, fallende Thrombozytenzahlen bzw. entgleisende Gerinnungsparameter beim HELLPSyndrom oder Anzeichen von fetalem Distress (pathologisches CTG). Auch bei einer schweren Präeklampsie mit Blutdruckwerten $\geq 170$ / $110 \mathrm{mmHg}$ und einer Proteinurie von mehr als $5 \mathrm{~g} / \mathrm{d}$ wird eine Prolongation der Schwangerschaft kritisch diskutiert. In diesen Situationen muss das mütterliche Risiko bei Prolongation der Schwangerschaft gegen den kindlichen Nutzen abgewogen werden. Nach 34 SSW sollte eine Schwangerschaft bei nachgewiesener Präeklampsie oder einem HELLP-Syndrom in jedem Fall beendet werden. Kommt es zu lebensbedrohlichen Komplikationen durch die Multisystemerkrankung, ist eine Überwachung der Patientin unter Intensivbedingungen erforderlich. Etwa $40 \%$ aller geburtshilflichen intensivmedizinischen Aufnahmen sind durch hypertensive Schwangerschaftserkrankungen bedingt [22].

\section{Behandlung der Hypertension}

Ein Nutzen für die fetale Entwicklung und somit eine Verbesserung der kindlichen Prognose durch eine medikamentöse Blutdrucksenkung konnte bisher nicht nachgewiesen werden. Aktuelle Metaanalysen zahlreicher Studien zur medikamentösen Blutdrucksenkung bei mäßiger Präeklampsie $(<170 / 110 \mathrm{mmHg}$ ) ergaben, dass diese mit einer erhöhten Rate wachstumsretardierter Neugeborener und einem verminderten Geburtsgewicht einhergeht [23].

Im Vordergrund der Therapie steht deshalb die Vermeidung maternaler zerebro- und kardiovaskulärer Komplikationen. Eine antihypertensive Therapie sollte erst bei Blutdruckwerten $\geq 170 / 110 \mathrm{mmHg}$ begonnen werden, bei vorbestehendem Hochdruck oder Pfropfkonstellation bereits ab Blutdruckwerten von $\geq 160 / 100 \mathrm{mmHg}$ [24]. Ziel der medikamentösen Therapie ist es, den Blutdruck auf Werte zwischen 140-160/90-100 mmHg zu senken. Unbehandelte Blutdruckwerte zwischen 160-170 systolisch und $100-110 \mathrm{mmHg}$ diastolisch sind aufgrund des maternalen Risikos nur kurzzeitig, asymptomatisch und nur unter stationärer Beobachtung zu tolerieren, da insbesondere bei Präeklampsie das zerebrale Gefäßsystem noch nicht an hohe Blutdruckwerte adaptiert ist und damit ein Durchbrechen der zerebrovaskulären Autoregulation mit Gefährdung durch die konsekutive zerebrale Hyperperfusion nicht auszuschließen ist.

Als medikamentöse Therapie kommen verschiedene Antihypertensiva in Betracht. Für die Langzeiteinstellung gilt das zentral an Alpharezeptoren agonistisch wirksame Methyldopa als Mittel der Wahl. Die maximale Dosierung beträt $2000 \mathrm{mg} / \mathrm{d}$ verteilt auf 4 Einzelgaben. Mittel der zweiten Wahl ist ein kardioselektiver Betablocker, der allerdings nicht bei intrauteriner Retardierung eingesetzt werden sollte, da neueste Metaanalysen geringere Geburtsgewichte unter Betablockertherapie beschreiben. Der Vasodilatator Dihydralazin wird heutzutage aufgrund seines ungünstigen maternalen Nebenwirkungsprofils (Kopfschmerzen, Reflextachykardie, Einschränkung der Nierenfunktion), das den Symptomen einer drohenden Eklampsie entspricht, kaum noch eingesetzt.

Table 2 Blood pressure reducing drugs for the acute situation.

\begin{tabular}{|c|c|c|c|}
\hline Active principle & Preparation (e.g.) & Dosage & \\
\hline \multirow[t]{2}{*}{ Calcium channel blocker (Nifedipine) } & Adalat $^{\circledR}$ & 5 mg capsules oral & possible repetition after $20 \mathrm{~min}$ \\
\hline & & initially $6 \mathrm{~mL} / \mathrm{h}$ i. v. (perfusor: $5 \mathrm{mg}$ in $50 \mathrm{~mL}$ ) & increase to max. $12 \mathrm{~mL} / \mathrm{h}$ \\
\hline Alpha-receptor blocker (Urapidil) & Ebrantil ${ }^{\circledR}$ & initially $3 \mathrm{mg} / \mathrm{h} \mathrm{i.v.}$ & increase to max. $24 \mathrm{mg} / \mathrm{h}$ \\
\hline Dihydralazine & Nepresol $^{\circledR}$ & $5 \mathrm{mg}$ as bolus i. v. & increase to max. $20 \mathrm{mg} / \mathrm{h}$ \\
\hline
\end{tabular}


Table 3 Prophylaxis of and therapy for eclampsia.

\begin{tabular}{|c|c|c|}
\hline Active principle & Dosage & Maintenance dose \\
\hline $\begin{array}{l}\text { Magnesium } \\
\text { sulphate }\end{array}$ & $\begin{array}{l}4-6 \mathrm{~g} \text { bolus } \\
\text { i.v. } / 20 \mathrm{~min}\end{array}$ & $1-3 \mathrm{~g} / \mathrm{h}$ \\
\hline & & for renewed attacks $2 \mathrm{~g}$ as bolus i.v. \\
\hline & & $\begin{array}{l}\text { for respiratory depression } \\
1 \mathrm{~g} \text { calcium gluconate } 10 \% \mathrm{i} \text {. v. }\end{array}$ \\
\hline Diazepam & $10 \mathrm{mg}$ i.v. & \\
\hline Phenytoin & $250 \mathrm{mg}$ i.v. & \\
\hline
\end{tabular}

min), oxygen saturation, and the patellar tendon reflex as a parameter of cerebral depression. The therapeutic range of magnesium in serum is $2-4 \mathrm{mmol} / \mathrm{L}$. Calcium gluconate is available as an antidote. The dosing of magnesium sulphate in acute situations can be seen in the following table ( Table 3 ).

\section{Treatment of Coagulopathy and Thrombocytopenia}

In cases of bleeding situations the administration of factor concentrates such as PPSB (prothrombin concentrate) at a dose of 20-25 IU/kg BW i.v. as well as erythro- and thrombocyte concentrates is indicated. At fibrinogen concentrations of $<2 \mathrm{~g} / \mathrm{L}$ fibrinogen should be administered at a dose of $2-4 \mathrm{~g}$ i.v. Persisting or recurrent bleeding can be indicative of hyperfibrinolysis developing from the DIC (disseminated intravascular coagulation) which can be treated with antifibrinolytic agents. A physiological $\mathrm{pH}$ value and a normal body temperature are prerequisites for haemostasis in the treatment of coagulopathy [27]. The relevance of glucocorticoid administration at a thrombocyte count below 100 thousand/ $\mathrm{LL}$ has not yet been completely clarified. Some studies show a rapid recovery of thrombocytes and an improvement in the clinical condition in comparison to placebo, whereas other studies were not able to confirm such findings [28]. Thrombocyte transfusions are only indicated for maternal bleeding or a thrombocytopenia of under 20 thousand $/ \mu \mathrm{L}$. Some experts recommend attainment of a thrombocyte count of 40 to 50 thousand/ $\mu \mathrm{L}$ prior to a planned Caesarean section [29]. In spite of the inhomogeneous data situation with regard to glucocorticoid administration ("conservative management of HELLP syndrome") and the lack of a randomised study on this topic, this procedure has become more and more established and, under the conditions of close foeto-maternal monitoring, is an option for pregnancies $<34$ th week. Methylprednisolone $\left(\right.$ Urbason $^{\circledR}$ ) is administered at a dose of $32 \mathrm{mg}$ per day up to $48 \mathrm{~h}$ post partum.

\section{Acute Renal Failure and Pulmonary Oedema}

These complications are on the whole very rare, but require in every case a close interdisciplinary management. In cases of oliguria, volume substitution should initially be performed under close monitoring of the excretions and retention values. If this therapy does not lead to a forced diuresis, a stepwise treatment with diuretics is indicated. Furosemide at a dose of $40 \mathrm{mg}$ per hour intravenously is the agent of choice in this situation. Hyperhydration with pulmonary oedema is a feared and serious complication. A low-dose dopamine therapy can have a beneficial effect in such situations by inducing selective vasodilatation in the kidney and splanchnic regions. Cases with manifest pulmonary oedema constitute an early indication for dialysis [30].
Die orale Medikation ist in folgender Tabelle zusammengestellt (๑Tab. 1).

Zur akuten Blutdrucksenkung kann der Kalziumkanalblocker Nifedipin in oraler Applikationsform eingesetzt werden. Für die intravenöse Therapie steht der Alpharezeptor-Antagonist Urapidil zur Verfügung. Die Dosierung ist aus folgender Tabelle ersichtlich ( Tab. 2).

\section{Behandlung der Eklampsie}

Magnesium wird als vasorelaxierendes Medikament in der Prophylaxe und Therapie der Eklampsie eingesetzt $[25,26]$. Durch Verminderung des zerebralen Gefäßwiderstands wird die Hirndurchblutung gesteigert und das Eklampsierisiko gesenkt. Eine Überdosierung kann zu einer Atemdepression führen, weshalb bei der intravenösen Magnesiumgabe die Atemfrequenz (>12/min), die Sauerstoffsättigung und der Patellarsehnenreflex als Parameter der zerebralen Depression überwacht werden sollten. Die therapeutische Breite des Magnesiumspiegels im Serum liegt zwischen 2-4 mmol/l. Als Antidot steht Kalziumglukonat zur Verfügung. Die Dosierung von Magnesiumsulfat in der Akutsituation kann folgender Tabelle entnommen werden (๑Tab. 3).

\section{Behandlung der Koagulopathie und Thrombozytopenie} In Blutungssituationen ist die Gabe von Faktorenkonzentraten wie PPSB (Prothrombinkonzentrat) in einer Dosierung von $20-25 \mathrm{IE} / \mathrm{kg}$ KG i.v. sowie Erythro- und Thrombozytenkonzentraten indiziert. Bei Fibrinogenkonzentrationen von $<2$ g/l sollte Fibrinogen in einer Dosierung von $2-4 \mathrm{~g}$ i.v. gegeben werden. Persistierende bzw. wieder neu auftretende Blutungen können auf eine sich aus der DIC entwickelnde Hyperfibrinolyse hindeuten, die mit Antifibrinolytika behandelt werden sollte. Bei der Behandlung der Koagulopathie sind für eine Hämostase ein physiologischer pH-Wert sowie eine normale Körpertemperatur Voraussetzung [27]. Die Bedeutung der Glukokortikoidgabe bei einer Thrombozytenzahl unter 100 Tsd/ $\mu l$ konnte bisher nicht abschließend geklärt werden. Einige Studien zeigen eine raschere Erholung der Thrombozyten und eine Verbesserung des klinischen Zustands im Vergleich zur Placebogabe, andere Studien konnten diese Ergebnisse nicht bestätigen [28]. Thrombozytentransfusionen sind lediglich bei maternalen Blutungen oder einer Thrombozytopenie von unter $20 \mathrm{Tsd} / \mu \mathrm{l}$ angezeigt. Einige Experten empfehlen, vor einem geplanten Kaiserschnitt Thrombozytenzahlen von 40 bis $50 \mathrm{Tsd} / \mu \mathrm{l}$ anzustreben [29]. Trotz der uneinheitlichen Datenlage bezüglich der Glukokortikoidgabe („,konservatives Management des HELLP-Syndroms“) und dem Fehlen einer randomisierten Studie zu diesem Thema, hat sich dieses Vorgehen mehr und mehr etabliert und ist unter der Voraussetzung einer engmaschigen fetomaternalen Überwachung eine Option bei Schwangerschaften < 34 SSW. Gegeben wird Methylprednisolon (Urbason ${ }^{\circledR}$ ) in einer Dosierung von $32 \mathrm{mg}$ täglich bis zu $48 \mathrm{~h}$ postpartal.

\section{Akutes Nierenversagen und Lungenödem}

Diese Komplikationen sind insgesamt sehr selten, erfordern aber in jedem Fall eine engmaschige interdisziplinäre Betreuung. Im Falle einer Oligurie sollte unter engmaschiger Überwachung der Ausscheidung und der Retentionswerte zunächst Volumen substituiert werden. Kommt es unter dieser Therapie nicht zur forcierten Diurese, ist eine dosierte Behandlung mit Diuretika indiziert. Furosemid in einer Dosierung von maximal $40 \mathrm{mg}$ pro Stunde intravenös ist in dieser Situation das Mittel der Wahl. Als schwerwiegende Komplikation ist eine Hyperhydratation mit Lungenödem zu befürchten. Eine LowDose-Dopamintherapie kann in dieser Situation durch eine selektive Vasodilatation im Nieren- und Splanchnikusgebiet gute Wirkung 


\section{Preventative Options}

$\nabla$

\section{ASA}

The use of ASA was discussed controversially for a long time. In a Cochrane analysis from 2007 encompassing 59 studies (> 37000 cases) it was found that the relative risk could be reduced from 25 to $17 \%$ [31]. The number needed to treat in the high-risk collective hereby amounted to 19 . The effect of aspirin was reported to produce "moderate but consistent benefits". In a meta-analysis by Bujold et al. from 2010 it became clear that the ASA effect is markedly higher when therapy is started before the 16th week of pregnancy [32]. In cases with an early start of therapy, the relative risk (RR) for preeclampsia is 0.47 and that for a severe preeclampsia is 0.09 , whereas the RRs are higher in cases with a later therapy start ( 0.81 for preeclampsia or, respectively, 0.26 for severe preeclampsia). In summary, we can conclude at this time point that the data situation definitely points to a measurable albeit not dramatic effect of ASA when therapy is started early. Until other, possibly more effective measures become available in the future, the ASA effect should not be ignored.

\section{Heparin}

Above all in cases of preeclampsia and IUGR at $<34$ th week of pregnancy, the spiral arteries in the placental bed exhibit characteristic changes in the form of acute atherosis, wall hypertrophy and luminal thrombosis. Prophylactic anticoagulation in highrisk patients is reported to have a preventative effect due to reduced thrombus formation and thus an improvement of uterine perfusion [33]. However, results from larger randomised studies that could confirm this hypothesis are still lacking. There does indeed appear to be a certain effect for women with thrombophilia [34]. A very recent meta-analysis did not reveal any significant effect of heparin in women who had had placental problems in a previous pregnancy [35]. Thus, the general use of heparin cannot be recommended and should be restricted to a few, clearly defined pregnant women (confirmed thrombophilia, anti-phospholipid syndrome).

\section{New Therapeutic Options and Future Perspectives}

From the results of animal experiments and human observations it is concluded that a reduction of circulating sFlt- 1 concentration should effect a regression or, respectively, improvement of preeclamptic symptoms. An inhibition of sFlt-1 by an antagonising antibody is indeed theoretically feasible, but is not realisable for human usage. The pharmacological intervention in a complex system of growth factors and their receptors generates potential side effects and thus test applications of such a procedure in pregnant women are too risky and ethically not justifiable. An alternative would be not to introduce an sFlt-1-inhibiting agent into the mother's body but rather to remove sFlt- 1 from it. This is technically possible by means of an apheresis technique. Earlier applications of lipid apheresis in pregnant women with familial disorders of lipid metabolism have shown that this methodology can be used during pregnancy without causing any problems for mother or baby. Some of the dextran columns used in apheresis are able to bind sFlt- 1 . This makes use of the fact that sFlt- 1 (like only a few other proteins) is positively charged and is thus bound to negative charges in the column. Preliminary in vitro experiments have shown that dextran columns can indeed effect a reduction of sFlt- 1 in blood. zeigen. Bei manifestem Lungenödem sollte frühzeitig die Indikation zur Dialyse gestellt werden [30].

\section{Präventive Ansätze}

\section{ASS}

Der Nutzen von ASS wurde lange Zeit kontrovers diskutiert. In einer Cochrane-Analyse aus dem Jahr 2007 unter Einschluss von 59 Studien (> 37000 Fälle) konnte gezeigt werden, dass das relative Risiko von 25 auf $17 \%$ gesenkt werden kann [31]. Die „number needed to treat" betrug hierbei im Hochrisikokollektiv 19. Der Effekt von Aspirin wird als moderat, aber konsistent beschrieben („moderate but consistent benefits“). In einer Metaanalyse von Bujold et al. aus dem Jahr 2010 wird deutlich, dass der ASS-Effekt deutlich höher ist, wenn mit der Therapie vor der 16. SSW begonnen wird [32]. Bei frühem Therapiebeginn ist für eine Präeklampsie das relative Risiko (RR) 0,47 und für eine schwere Präeklampsie 0,09, wogegen das RR bei späterem Therapiebeginn höher ist (0,81 für Präeklampsie bzw. 0,26 für schwere Präeklampsie). Zusammenfassend lässt sich zu diesem Punkt feststellen, dass die Datenlage bei frühzeitigem Therapiebeginn definitiv einen messbaren, wenn auch nicht dramatischen Effekt von ASS beschreibt. Bis zukünftige Maßnahmen eventuell besser wirken, sollte man den ASS-Effekt nicht ungenutzt lassen.

\section{Heparin}

Vor allem bei Präeklampsien und IUGR < 34 SSW zeigen die Spiralarterien im Plazentabett charakteristische Veränderungen in Form von akuter Atherose, Wandhypertrophie und luminaler Thrombose. Der prophylaktischen Antikoagulation von Hochrisikopatientinnen wird ein präventiver Effekt durch verminderte Thrombenbildung und damit Verbesserung der uterinen Perfusion zugeschrieben [33]. Bisher fehlen jedoch Ergebnisse großer randomisierter Studien, die diese These belegen könnten. Für Frauen mit Thrombophilie scheint es einen gewissen Effekt zu geben [34]. Eine aktuelle Metaanalyse belegt keinen signifikanten Effekt von Heparin bei Frauen mit einer plazentaren Problematik in einer vorausgegangenen Schwangerschaft [35]. Somit kann derzeit der allgemeine Einsatz von Heparin nicht empfohlen werden und sollte auf wenige, klar definierte Schwangere (nachgewiesene Thrombophilie, Antiphospholipid-Syndrom) beschränkt sein.

\section{Neue Therapieoptionen und Zukunftsaussichten $\nabla$}

Aus tierexperimentellen Ansätzen und einer humanen Beobachtung war die Schlussfolgerung gezogen worden, dass eine Verminderung der zirkulierenden sFlt-1-Konzentration einen Rückgang bzw. eine Verbesserung der präeklamptischen Symptome bewirken müsste. Eine Inhibition von sFlt-1 durch einen antagonisierenden Antikörper ist zwar theoretisch denkbar, in der humanen Anwendung aber nicht praktikabel. Der pharmakologische Eingriff in ein komplexes System aus Wachstumsfaktoren und deren Rezeptoren generiert potenzielle Nebeneffekte, und somit ist dieses Vorgehen bezüglich der Testung an Schwangeren zu riskant und ethisch nicht vertretbar. Eine Alternative wäre es, nichts sFlt-1-Inhibierendes in den mütterlichen Körper einzubringen, sondern sFlt-1 herauszuholen. Dies ist technisch mittels einer Apheresetechnik möglich. Frühere Anwendungen einer Lipidapherese bei Schwangeren mit familiärer Fettstoffwechselstörung haben die Erfahrung gebracht, dass diese Methode in der Schwangerschaft ohne Probleme für Mutter und Kind eingesetzt werden kann. Einige der in der Apherese verwendeten Dextransäulen sind in der 
In a pilot study by the Harvard Medical School Boston and the University Hospitals in Cologne and Leipzig, 8 pregnant women were treated in this way for the first time [36]. The apheresis was well tolerated by the pregnant women and had no detrimental effects on the foetus. By means of an about 2-hour apheresis treatment it is possible to reduce the maternal sFlt- 1 concentration by $25-30 \%$. This leads to a rapid and pronounced decrease of the proteinuria. In some of the study participants the procedure was repeated several times (up to 4 times). It was possible thereby to serially achieve and maintain the sFit-1 level - that always increased again after each apheresis treatment - in a range at which a prolongation of the pregnancy could be undertaken and which would not have been possible by the usual expectative management.

Thus a first promising step has been made on the way to a truly therapeutic intervention for preeclampsia. Even with just these first few patients in a pilot study, it has been shown that by use of extracorporeal sFit-1 apheresis the clinical state of the pregnant patients can be stabilised to such an extent that a measurable prolongation of pregnancy is possible. Finally, with the realistic existence of a therapeutic option, the measurement of angiogenic factors in maternal blood has gained a fundamentally new relevance.

Recent molecular biological studies have furnished new knowledge on the regulation of early trophoblasts which may also open up new intervention options. Finally, it has become clear that placental sFlt-1 production is not the causal mechanism of preeclampsia, but is rather a common pathway that causes the clinical symptoms which can be triggered by various mechanisms (e.g., hypoxia). PPAR- $\gamma$ (peroxisome proliferator-activated receptor- $\gamma$ ) is a placental transcription factor with positive effects in regard to endothelial-mediated vasodilatation. In a rat model with reduced uterine perfusion (RUPP) a PPAR- $\gamma$ agonist was able to improve some the preeclampsia-like symptoms. Treatment of pregnant rats with a PPAR- $\gamma$ antagonist also led to changes such as hypertension, proteinuria, reduced foetal weight and up-regulates Flt-1 production [37,38]. Although the way from these data to a realistic therapeutic option is long, such findings do indeed potentially provide targets for innovative strategies for future disease management.

\section{Conflicts of Interest \\ $\nabla$}

Holger Stepan has received lecture and advisor fees from Roche Diagnostics.
Lage, sFlt-1 zu binden. Dabei macht man sich den Umstand zunutze, dass sFlt-1 (wie wenige Proteine) positiv geladen ist und durch die negative Ladung der Säule gebunden wird. Erste In-vitro-Experimente zeigten, dass Dextransäulen tatsächlich eine sFlt-1-Reduktion im Blut bewirken können.

In einer Pilotstudie der Harvard Medical School Boston und der Universitätsklinika Köln und Leipzig wurden erstmals 8 Schwangere behandelt [36]. Die Apherese wurden von den Schwangeren gut toleriert und bewirkte keine Beeinträchtigungen des Feten. Durch eine ca. 2-stündige Apheresebehandlung war es möglich, die maternale sFlt-1-Konzentration um 25-30\% zu senken. Dies führte zu einer raschen und deutlichen Abnahme der Proteinurie. Bei einem Teil der Studienpatientinnen wurde das Treatment mehrmals (bis zu 4-mal) durchgeführt. Damit war es möglich, die nach der Apherese immer wieder ansteigenden sFlt-1-Level seriell in einen Bereich zu bringen und zu halten, mit dem eine Schwangerschaftsprolongation erreicht werden konnte, die mit herkömmlichem expektativen Management nicht möglich gewesen wäre.

Somit ist ein erster hoffnungsvoller Schritt gemacht auf einem Weg hin zu einer wirklichen therapeutischen Intervention bei Präeklampsie. Selbst bei diesen ersten, wenigen Pilotpatientinnen konnte gezeigt werden, dass über diesen Ansatz einer extrakorporalen sFlt-1Apherese der klinische Zustand der Schwangeren so stabilisiert werden kann, dass eine messbare Schwangerschaftsprolongotion ermöglicht wird. Letztendlich kommt mit dem realistischen Bestehen einer therapeutischen Option der Messung der angiogenen Faktoren im mütterlichen Blut eine fundamental neue Rolle zu.

Neuere molekularbiologische Untersuchungen erbrachten Erkenntnisse über die Regulation des frühen Trophoblasten, die möglicherweise auch Interventionsmöglichkeiten eröffnen. Letztendlich ist klar geworden, dass die plazentare sFlt-1-Produktion nicht die kausale Ursache der Präeklampsie, sondern ein gemeinsamer, die klinische Symptomatik hervorrufender Pathway ist, der durch unterschiedliche Mechanismen (z.B. Hypoxie) induziert werden kann. PPAR- $\gamma$ (peroxisome proliferator-activated receptor- $\gamma$ ) ist ein plazentarer Transkriptionsfaktor mit positiven Effekten bezüglich der endothelvermittelten Vasodilatation. In einem Rattenmodell mit reduzierter uteriner Perfusion (RUPP) ist ein PPAR- $\gamma$-Agonist in der Lage, einige der Präeklampsie-ähnlichen Symptome zu verbessern. Die Behandlung von schwangeren Ratten mit einem PPAR- $\gamma$-Antagonisten führte indes zu Veränderungen wie Hypertonie, Proteinurie, reduziertem Fetalgewicht und hochregulierter sFlt-1-Produktion [37,38]. Obwohl es von diesen Daten zu einer realistischen therapeutischen Option noch ein weiter Weg ist, liefern solche Erkenntnisse doch potenzielle Targets für innovative Ansätze einer künftigen Behandlung.

\section{Interessenkonflikt}

$\nabla$

Holger Stepan hat Vortrags- und Beraterhonorare von Roche Diagnostics erhalten. 


\section{References}

1 Walker JJ. Pre-eclampsia. Lancet 2000; 356:1260-1265

2 Bolte AC, van Geijn HP, Dekker GA. Management and monitoring of severe preeclampsia. Eur J Obstet Gynecol Reprod Biol 2001; 96: 8-20

3 Goldenberg RL, Culhane JF, Iams JD et al. Epidemiology and causes of preterm birth. Lancet 2008; 371: 75-84

4 Smith GC, Pell JP, Walsh D. Pregnancy complications and maternal risk of ischaemic heart disease: a retrospective cohort study of 129,290 births. Lancet 2001; 357: 2002-2006

5 Garovic VD, Hayman SR. Hypertension in pregnancy: an emerging risk factor for cardiovascular disease. Nat Clin Pract Nephrol 2007; 3: 613622

6 Huppertz B. Placental origins of preeclampsia: challenging the current hypothesis. Hypertension 2008; 51: 970-975

7 Huppertz B. Placental pathology in pregnancy complications. Thromb Res 2011; 127 (Suppl. 3): S96-S99

8 Roberts JM, Taylor RN, Musci TJ et al. Preeclampsia: an endothelial cell disorder. Am J Obstet Gynecol 1989; 161: 1200-1204

9 Levine RJ, Maynard SE, Qian C et al. Circulating angiogenic factors and the risk of preeclampsia. N Engl J Med 2004; 350: 672-683

10 Staff AC, Braekke K, Harsem NK et al. Circulating concentrations of sFlt1/ Soluble fms-like tyrosine kinase 1 in fetal and maternal serum during pre-eclampsia. Eur J Obstet Gynecol Reprod Biol 2005; 122: 33-39

11 Chaiworapongsa T, Romero R, Kim YM et al. Plasma soluble vascular endothelial growth factor receptor-1 concentration is elevated prior to the clinical diagnosis of pre-eclampsia. J Matern Fetal Neonatal Med 2005; $17: 3-18$

12 Hladunewich M, Ananth Karumanchi S, Lafayette R. Pathophysiology of the clinical manifestations of preeclampsia. Clin J Am Soc Nephrol 2007; 2: 543-549

13 Osmanagaoglu MA, Karahan SC, Aran T et al. Predictive value of plasma total carnitine, arginine, asymmetric dimethylarginine and ischemiamodified albumin levels and their combined use in the early detection of preeclampsia. Geburtsh Frauenheilk 2011; 71: 773-778

14 Milne F, Redman C, Walker J et al.; PRECOG II Group. Assessing the onset of pre-eclampsia in the hospital day unit: summary of the pre-eclampsia guideline (PRECOG II). BMJ 2009; 339: b3129

15 Stepan H, Schaarschmidt W, Jank A et al. Angiogene Faktoren zur Diagnosesicherung bei Präeklampsie in der klinischen Routine: erste Erfahrungen. Z Geb Neonatol 2010; 214: 234-238

16 Verlohren S, Herraiz I, Lapaire 0 et al. The sFlt-1/PIGF ratio in different types of hypertensive pregnancy disorders and its prognostic potential in preeclamptic patients. Am J Obstet Gynecol 2012; 206: 58.e1-58.e8

17 Rana S, Hacker MR, Modest AM et al. Circulating angiogenic factors and risk of adverse maternal and perinatal outcomes in twin pregnancies with suspected preeclampsia. Hypertension 2012; 60: 451-458

18 Poon LC, Maiz N, Valencia C et al. First-trimester maternal serum pregnancy-associated plasma protein-A and pre-eclampsia. Ultrasound Obstet Gynecol 2009; 33: 23-33

19 Lapaire O, Shennan A, Stepan H. The preeclampsia biomarkers soluble fms-like tyrosine kinase- 1 and placental growth factor: current knowledge, clinical implications and future application. Eur J Obstet Gynecol Reprod Biol 2010; 151: 122-129

20 Akolekar R, Syngelaki A, Sarquis R et al. Prediction of early, intermediate and late pre-eclampsia from maternal factors, biophysical and biochemical markers at 11-13 weeks. Prenat Diagn 2011; 31: 66-74

21 Rath W, Fischer T, Klockenbusch W. Diagnostik und Therapie hypertensiver Schwangerschaftserkrankungen. Leitlinie der Arbeitsgemeinschaft Schwangerschaftshochdruck/Gestose der Deutschen Gesellschaft für Gynäkologie und Geburtshilfe e.V. (DGGG), AWMF-Leitlinien-Register Nr. 015/018, letzte Aktualisierung 05/2008
22 Panchal S, Arria AM, Harris AP. Intensive care utilization during hospital admission for delivery: prevalence, risk factors, and outcomes in a statewide population. Anesthesiology 2000; 92: 1537-1544

23 Abalos E, Duley L, Steyn DW et al. Antihypertensive drug therapy for mild to moderate hypertension in pregnancy. Cochrane Database Syst Rev 2007; 1: CD002252

24 Ferrer RL, Sibai BM, Multrow CD et al. Management of mild chronic hypertension during pregnancy: a review. Obstet Gynecol 2000; 96: 849860

25 Helewa ME, Burrows RF, Smith J et al. Report of the Canadian Hypertension Society consensus conference: 1. Definitions, evaluations and classification of hypertensive disorders in pregnancy. CMAJ 1997; 157: 715

26 Lucas MJ, Leveno KJ, Cunnningham FG. A comparison of magnesium sulfate with phenytoin for the prevention of eclampsia. N Engl J Med 1995; 333: 201

27 Schott M, Henkelmann A, Meinkoehn Yet al. Postpartale Eklampsie und fulminantes HELLP-Syndrom. Anaesthesist 2011; 60: 343-351

28 Woudstra DM, Chandra S, Hofmeyr GJ et al. Corticosteroids for HELLP (hemolysis, elevated liver enzymes, low platelets) syndrome in pregnancy. Cochrane Database Syst Rev 2010; 9: CD008148

29 Sibai BM. Diagnosis, controversies, and management of the syndrome of hemolysis, elevated liver enzymes and low platelet count. Obstet Gynecol 2004; 103: 981

30 Klockenbusch W, Fischer T. Präeklampsie. Kapitel 8: Medikamentöse Therapie. Bremen: Uni-Med; 2005: 76-80

31 Duley L, Henderson-Smart DJ, Meher S et al. Antiplatelet agents for preventing pre-eclampsia and its complications. Cochrane Database Syst Rev 2007; 2: CD004659

32 Bujold E, Roberge S, Lacasse Y et al. Prevention of preeclampsia and intrauterine growth restriction with aspirin started in early pregnancy: a meta-analysis. Obstet Gynecol 2010; 116 (2 Pt 1): 402-414

33 Rey E, Garneau P, David M et al. Dalteparin for the prevention of recurrence of placental-mediated complications of pregnancy in women without thrombophilia: a pilot randomized controlled trial. J Thromb Haemost 2009; 45: 86

34 Kupferminc MJ, Rimon E, Many A et al. Low molecular weight heparin treatment during subsequent pregnancies of women with inherited thrombophilia and previous severe pregnancy complications. J Matern Fetal Neonatal Med 2011; 24: 1042-1045

35 Martinelli I, Ruggenenti P, Cetin I et al.; HAPPY Study Group. Heparin in pregnant women with previous placenta-mediated pregnancy complications: a prospective, randomized, multicenter, controlled clinical trial. Blood 2012; 119: 3269-3275

36 Thadhani R, Kisner T, Hagmann H et al. Pilot study of extracorporeal removal of soluble fms-like tyrosine kinase 1 in preeclampsia. Circulation 2011; 124: 940-950

37 McCarthy FP, Drewlo S, English FA et al. Evidence implicating peroxisome proliferator-activated receptor- $\gamma$ in the pathogenesis of preeclampsia. Hypertension 2011; 58: 882-887

38 McCarthy FP, Drewlo S, Kingdom J et al. Peroxisome proliferator-activated receptor- $\gamma$ as a potential therapeutic target in the treatment of preeclampsia. Hypertension 2011; 58: 280-286

39 Elsen C, Rivas-Echeverría C, Sahland K et al. Vitamins E, A and $\mathrm{B}_{2}$ as possible risk factors for preeclampsia - under consideration of the PROPER study ("Prevention of preeclampsia by high-dose riboflavin supplementation"). Geburtsh Frauenheilk 2012; 72: 846-852

Deutschsprachige Zusatzinformationen online abrufbar unter: www.thieme-connect.de/ejournals/toc/gebfra. 